\title{
IMPLEMENTASI PERAN KOMITE SEKOLAH DI SD NEGERI SUMBERPORONG 03 KECAMATAN LAWANG, KABUPATEN MALANG
}

\author{
Mawan Kriswantono, Muhyadi \\ ITN Malang, Universitas Negeri Yogyakarta \\ mawan_krs@yahoo.co.id,muhyadi@uny.ac.id
}

\begin{abstract}
Abstrak
Penelitian ini bertujuan untuk mendeskripsikan peran komite sekolah sebagai: 1) badan pertimbangan, 2) badan pendukung, 3) badan pengontrol, dan 4) badan penghubung di SD Negeri Sumberporong 03 Lawang, Kabupaten Malang. Penelitian ini menggunakan pendekatan kualitatif. Data diperoleh melalui wawancara dan dokumentasi dari ketua dan anggota komite sekolah, kepala sekolah, dan guru. Analisis data menggunakan analisis interaktif dengan mendasarkan pada proses reduksi data, penyajian data, dan penarikan kesimpulan. Pengujian validitas data menggunakan triangulasi. Hasil penelitian ini menunjukkan bahwa komite sekolah di SD Negeri Sumberporong 03 Lawang, Kabupaten Malang secara umum telah melaksanakan perannya sebagaimana yang diharapkan. Komite sekolah telah melaksanakan perannya sebagai badan pertimbangan, pendukung, dan penghubung. Namun dalam hal pengontrol kebijakan dan program sekolah, komite sekolah belum sepenuhnya melaksanakannya, karena komite sekolah sebagai organisasi yang bersifat sosial dan masing-masing anggota komite mempunyai kesibukan dalam profesi masing-masing sehingga belum mampu melaksanakan kontrol secara langsung di sekolah.
\end{abstract}

Kata kunci: peran, komite sekolah

\section{THE IMPLEMENTATION OF THE SCHOOL COMMITTEE'S ROLE IN SUMBERPORONG 03 STATE ELEMENTARY SCHOOL, LAWANG, MALANG REGENCY}

\section{Abstract}

The objective of this study is to describe the role of the school committee as: 1) advisory agency, 2) supporting agency, 3) controlling agency, and 4) mediator agency in Sumberporong 03 State Elementary School Lawang, Malang Regency. The method of this study is a qualitative approach. The data were collected through interview and documentation of the components and the head of school committee, the headmaster, and the teachers of the school. The technique of data analysis was interactive analysis based on data reduction process, data presentation, and conclusion drawing. The data validation used triangulation. The results of this study indicate that the school committee of Sumberporong 03 State Elementary School Lawang, Malang Regency in principle carries out its role as expected. The school committee has been carrying out its role as the consideration agency, support and liaison. However, in terms of policy and school program controller, the school committee has not been fully implemented it, because the school committee is a social organization and the respective committee members have a business in their respective professions so that they have not been able to control the program at the school directly.

Keywords: role, school committee 


\section{Pendahuluan}

Wacana desentralisasi pendidikan muncul sejak diberlakukannya UndangUndang No-mor 22 Tahun 1999 tentang Pemerintahan Daerah. Pasal 11 UndangUndang Nomor 22 Tahun 1999 menyebutkan bahwa pendidikan merupakan salah satu bidang pemerintahan yang wajib dilaksanakan oleh pemerintah daerah. Kebijakan ini memberikan kesempatan dan keleluasaan kepada daerah untuk memberdayakan pendidikan berdasarkan kebutuhan masyarakat setempat. Pemerintah daerah diharapkan senantiasa meningkatkan kemampuannya dalam berbagai tahap pembangunan pendidikan, sejak tahap perumusan kebijakan daerah, perencanaan, pelaksanaan, sampai pemantauan di daerah masing-masing.

Dalam konteks desentralisasi manajemen pendidikan, pemerintah berusaha untuk mengurangi campur tangan atau intervensi pejabat atau unit pusat terhadap persoalan pendidikan yang sepatutnya bisa diputuskan dan dilaksanakan oleh unit di tataran bawah, pemerintah daerah, atau masyarakat. Salah satu wujud desentralisasi pendidikan adalah Manajemen Berbasis Sekolah (MBS). Dalam MBS, sekolah dan masyarakat diberikan kewenangan mengelola sekolah untuk meningkatkan mutu. Namun demikian, betapapun luasnya otonomi dalam pendidikan yang diberikan, tetap harus konsisten mengacu pada sistem konstitusi di Indonesia

Dalam rangka pelaksanaan manajemen berbasis sekolah sebagai bagian dari otonomi pendidikan, maka untuk meningkatkan peran serta masyarakat, diperlukan suatu wadah yang dapat mengakomodasikan pandangan, aspirasi dan menggali potensi masyarakat untuk menjamin terciptanya demokratisasi, transparansi, dan akuntabilitas pendidikan. Wadah tersebut adalah dewan pendidikan di tingkat kabupaten/kota dan komite sekolah di tingkat satuan pendidikan. Keberadaan dewan pendidikan dan komite sekolah ini mengacu kepada Undang-Undang Nomor 25 Tahun 2000 tentang Progam Pembangunan
Nasional (Propenas) Tahun 2000-2004, dan sebagai implementasi dari undang-undang tersebut telah diterbitkan Keputusan Menteri Pendidikan Nasional Nomor 044/U/ 2002 tanggal 2 April 2002 tentang Dewan Pendidikan dan Komite Sekolah.

Berdasarkan Keputusan Menteri Pendidikan Nasional Nomor 044/U/2002, komite sekolah adalah badan mandiri yang mewadahi peran serta masyarakat dalam rangka meningkatkan mutu, pemerataan, dan efisiensi pengelolaan pendidikan di tingkat satuan pendidikan.

\section{Pengertian Komite Sekolah}

Dalam perkembangan tuntutan aspirasi masyarakat terhadap penyelenggara satuan pendidikan, maka dibentuk komite sekolah sesuai dengan Keputusan Menteri Pendidikan Nasional Nomor 044/U/2002 tentang Dewan Pendidikan dan Komite Sekolah. Komite sekolah adalah badan mandiri yang mewadahi peran serta masyarakat dalam rangka meningkatkan mutu, pemerataan, dan efisiensi pengelolaan pendidikan di satuan pendidikan baik dari jalur pendidikan prasekolah, jalur pendidikan sekolah maupun pendidikan luar sekolah.

Komite sekolah adalah nama badan yang berkedudukan pada satuan pendidikan, baik jalur sekolah maupun luar sekolah. Nama komite sekolah adalah satu nama yang generik. Artinya, bahwa nama badan disesuaikan dengan kondisi dan kebutuhan masing-masing satuan pendidikan, seperti komite sekolah, komite pendidikan, komite pendidikan luar sekolah, dewan sekolah, majelis sekolah, majelis madrasah, komite TK, atau nama lain yang disepakati.

\section{Kedudukan dan Sifat Komite Sekolah}

Komite sekolah merupakan suatu badan yang mandiri dan berkedudukan di satuan pendidikan, tidak mempunyai hubungan hierarkis dengan lembaga pemerintahan. Sesuai dengan Keputusan Menteri Pendidikan Nasional Nomor 044/U/ 2002, bahwa kedudukan dan sifat komite sekolah adalah sebagai berikut: 
- Komite sekolah berkedudukan di satuan pendidikan;

- Komite sekolah dapat terdiri atas satu satuan pendidikan, atau beberapa satuan pendidikan dalam jenjang yang sama, atau beberapa satuan pendidikan yang berbeda jenjang tetapi berada pada lokasi yang berdekatan, atau satuansatuan pendidikan yang dikelola oleh suatu penyelenggara pendidikan, atau karena pertimbangan lainnya;

- Badan ini bersifat mandiri, tidak mempunyai hubungan hierarkis dengan lembaga pemerintahan.

Komite sekolah dan sekolah memiliki kemandirian masing-masing, tetapi tetap sebagai mitra yang harus saling bekerja sama sejalan dengan konsep manajemen berbasis sekolah (MBS). Dari uraian tersebut dapat dikatakan bahwa satuan pendidikan tidak memiliki kewenangan untuk menentukan kebijakan dalam komite sekolah.

\section{Organisasi Komite Sekolah}

Keanggotaan komite sekolah berasal dari unsur-unsur yang ada dalam masyarakat, dewan guru, yayasan atau lembaga penyelenggara pendidikan, badan pertimbangan desa dapat pula dilibatkan sebagai komite sekolah. Dalam Keputusan Menteri Pendidikan Nasional Nomor 044/U/2002 serta Peraturan Pemerintah Nomor 17 Tahun 2010 tentang Pengelolaan dan Penyelenggaraan Pendidikan, mensyaratkan secara rinci organisasi komite sekolah sebagai berikut:

\section{Keanggotaan Komite Sekolah}

Unsur masyarakat dapat berasal dari : (1) orang tua/wali peserta didik, (2) tokoh masyarakat, (3) tokoh pendidikan, (4) dunia usaha, (5) organisasi profesi tenaga pendidikan, (6) wakil alumni.

Unsur dewan guru, yayasan/lembaga penyelenggara pendidikan Badan Pertimbangan Desa dapat pula dilibatkan sebagai anggota komite sekolah (maksimal 3 orang).
Anggota komite sekolah sekurangkurangnya berjumlah 9 (sembilan) orang dan jumlahnya gasal.

Kepengurusan Komite Sekolah:

Pengurus sekurang-kurangnya terdiri atas: (1) Ketua, (2) Sekretaris, (3) Bendahara. Pengurus dipilih dari dan oleh anggota. Ketua bukan berasal dari kepala satuan pendidikan.

\section{Anggaran Dasar (AD) dan Anggaran Rumah} Tangga (ART)

- Komite sekolah wajib memiliki AD dan ART

- Anggaran Dasar sebagaimana dimaksud sekurang-kurangnya memuat: (1) Nama dan tempat kedudukan, (2) Dasar, tujuan dan kegiatan, (3) Keanggotaan dan kepengurusan, (4) Hak dan kewajiban anggota dan pengurus, (5) Keuangan, (6) Mekanisme kerja dan rapat-rapat, (7) Perubahan AD dan ART serta pembubaran organisasi.

Tujuan Komite sekolah

Menurut Surat Keputusan Mendiknas Nomor 044/U/2002, tujuan dibentuknya komite sekolah sebagai suatu organisasi masyarakat sekolah adalah sebagai berikut:

- Mewadahi dan menyalurkan aspirasi dan prakarsa masyarakat dalam melahirkan kebijakan operasional dan program pendidikan di tingkat satuan pendidikan.

- Meningkatkan tanggung jawab dan peran serta masyarakat dalam penyelenggaraan pendidikan di tingkat satuan pendidikan.

- Menciptakan suasana dan kondisi transparan, akuntabel, dan demokratis dalam penyelenggaraan dan pelayanan pendidikan yang bermutu di tingkat satuan pendidikan.

Dengan demikian tujuan dibentuknya komite sekolah adalah untuk mewadahi partisipasi para stakeholder agar turut serta dalam operasional manajemen sekolah sesuai dengan peran dan fungsinya, berkenaan dengan perencanaan, pelaksa- 
naan dan evaluasi program sekolah secara proporsional, sehingga komite sekolah dapat memberdayakan masyarakat dan meningkatkan mutu pendidikan.

\section{Peran dan Fungsi Komite Sekolah}

Peran dan fungsi pokok komite sekolah tertuang dalam Keputusan Menteri Pendidikan Nasional Nomor 044/U/2002 tanggal 2 April 2002 tentang Dewan Pendidikan dan Komite Sekolah adalah sebagai berikut:

- Pemberi pertimbangan (advisory agency) dalam penentuan dan pelaksanaan kebijakan pendidikan di satuan pendidikan.

- Komite sekolah dalam fungsinya sebagai badan pertimbangan bagi sekolah, dalam kaitannya dengan pengelolaan sumber daya pendidikan antara lain berperan mengidentifikasi berbagai potensi sumber daya pendidikan yang ada dalam masyarakat. Fungsi ini akan dapat berguna dalam memberikan pertimbangan mengenai sumber daya pendidikan yang ada dalam masyarakat yang dapat diperbantukan di sekolah.

- Pendukung layanan pendidikan (supporting agency), baik yang berwujud finansial, pemikiran, maupun tenaga dalam penyelenggaraan pendidikan satuan pendidikan.

- Fungsi komite sekolah sebagai badan pendukung terdiri atas pengelolaan sumber daya, sarana dan prasarana, dan pengelolaan anggaran.

- Pengontrol (controlling agency) dalam rangka transparansi dan akuntabilitas penyelenggaraan dan keluaran pendidikan di satuan pendidikan.

- Fungsi komite sekolah sebagai badan pengontrol terdiri atas mengontrol perencanaan pendidikan di sekolah, memantau pelaksanaan program sekolah, dan memantau out put pendidikan.

- Mediator antara pemerintah (eksekutif) dengan masyarakat di satuan pendidikan.

- Fungsi komite sekolah sebagai badan penghubung terdiri atas perencanaan, pelaksana-an program, dan pengelolaan sumber daya pendidikan.
Wewenang dan Kegiatan Pokok Komite Sekolah

Nanang Fattah (2004, p.121) menyatakan bahwa komite sekolah mempunyai wewenang sebagai berikut:

- Menetapkan Anggaran Dasar dan Anggaran Rumah Tangga komite sekolah.

- Bersama-sama sekolah menetapkan rencana strategi pengembangan sekolah.

- Bersama-sama sekolah menetapkan standar pelayanan sekolah.

- Bersama-sama sekolah membahas bentuk kesejahteraan personil sekolah.

- Bersama-sama sekolah menetapkan RAPBS.

- Mengkaji pertanggungjawaban program sekolah.

- Mengkaji dan menilai kinerja sekolah.

- Merekomendasikan kepada sekolah atau guru yang berprestasi dan memenuhi persyaratan profesionalisme serta administratif secara normatif sesuai dengan landasan hukum untuk promosi dan diajukan kepada pihak berwenang, dalam hal ini Kepala Dinas Pendidikan kota/kabupaten.

- Menerima kepala sekolah dan guru yang dipromosikan oleh sekolah lain sesuai dengan persyaratan profesionalisme serta administratif secara normatif sesuai dengan landasan hukum untuk dipromosikan dan ditunjuk oleh pihak yang berwenang.

- Merekomendasikan kepada sekolah atau guru yang melanggar etika profesionalisme serta administratif secara normatif sesuai dengan landasan hukum yang berlaku dan diajukan kepada pihak yang berwenang, dalam hal ini kepala Kantor Dinas Pendidikan kota/ kabupaten.

\section{Tugas Pokok Komite Sekolah}

Selanjutnya Nanang Fattah (2004, pp.122-123) menyatakan bahwa komite sekolah mempunyai tugas pokok sebagai berikut:

- Menyelenggarakan rapat-rapat komite sesuai dengan program yang telah ditetapkan. 
- Bersama-sama sekolah merumuskan dan menetapkan visi dan misi sekolah.

- Bersama sekolah menyusun standar pelayanan pembelajaran di sekolah.

- Bersama-sama sekolah menyusun rencana strategi pengembangan sekolah.

- Bersama-sama sekolah menyusun dan menetapkan rencana program tahunan sekolah termasuk RAPBS.

- Membahas dan turut menetapkan pemberian tambahan kesejahteraan berupa uang honorarium yang diperoleh dari masyarakat kepada sekolah, tenaga guru dan tenaga administratif sekolah.

- Bersama-sama sekolah mengembangkan potensi unggulan, baik yang bersifat akademis maupun non akademis.

- Menghimpun dan menggali sumber dana dari masyarakat untuk meningkatkan kualitas pelayanan sekolah.

- Mengelola kontribusi masyarakat berupa uang yang diberikan kepada sekolah.

- Mengelola kontribusi masyarakat yang berupa non material (tenaga, pikiran) yang diberikan kepada sekolah.

- Mengevaluasi program sekolah secara profesional sesuai dengan kesepakatan pihak sekolah, meliputi: pengawasan sarana dan prasarana sekolah, pengawas keuangan secara berkala dan berkesinambungan.

- Mengidentifikasi berbagai permasalahan dan memecahkannya bersama-sama dengan pihak sekolah.

- Memberikan respon terhadap kurikulum yang dikembangkan secara standar nasional maupun lokal.

- Memberikan motivasi dan penghargaan kepada tenaga pendidik dan kependidikan.

- Memberikan otonomi secara profesional kepada guru mata pelajaran dalam melaksanakan tugas-tugas kependidikannya sesuai dengan kaidah dan kompetensi guru.

- Membangun jaringan kerja sama dengan pihak luar sekolah yang bertujuan untuk meningkatkan kualitas pelayanan proses dan hasil pendidikan di sekolah.

- Memantau kualitas proses pelayanan dan hasil pendidikan di sekolah.
- Mengkaji laporan pertanggungjawaban pelaksanaan program yang dikonsultasikan oleh kepala sekolah.

- Menyampaikan usul atau rekomendasi kepada pemerintah daerah untuk meningkatkan kualitas pelayanan pendidikan sesuai dengan kebutuhan sekolah.

Indikator Kinerja Komite Sekolah

Menurut buku panduan Indikator Komite Sekolah yang dikeluarkan oleh Tim Pengembangan Komite Sekolah Ditjen Dikdasmen, bahwa komponen dan indikator kinerja komite sekolah terkait pada peran yang dilakukannya, yakni sebagai badan pertimbangan (advisory agency), pendukung (supporting agency), pengawas (controlling agency), dan badan mediator (mediator agency).

Tim Pengembangan Komite Sekolah Ditjen Dikdasmen (Depdiknas: 2004) juga menyatakan bahwa pembentukan komite sekolah harus memperhatikan pembagian peran sesuai dengan posisi dan otonomi yang ada. Adapun peran yang dijalankan komite sekolah adalah sebagai berikut:

- Pemberi pertimbangan (advisory agency) dalam penentuan dan pelaksanaan kebijakan pendidikan di satuan pendidikan: Identifikasi sumber daya pendidikan dalam masyarakat. Memberikan masukan untuk penyusunan RAPBS. Menyelenggarakan rapat RAPBS (sekolah, orang tua siswa masyarakat). Memberikan pertimbangan perubahan RAPBS.; Ikut mengesahkan RAPBS bersama kepala sekolah. Memberikan masukan terhadap proses pengelolaan pendidikan di sekolah. Memberikan masukan terhadap proses pembelajaran kepada para guru. Identifikasi potensi sumber daya pendidikan dalam masyarakat. Memberikan pertimbangan tentang tenaga kependidikan yang dapat diperbantukan di sekolah. Memberikan pertimbangan tentang sarana dan prasarana yang dapat diperbantukan di sekolah. Memberikan pertimbangan tentang anggaran yang dapat dimanfaatkan di sekolah. 
- Pendukung (supporting agency), baik yang berwujud finansial, pemikiran, maupun tenaga dalam penyelenggaraan pendidikan di satuan pendidikan: Memantau kondisi ketenagaan pendidikan di sekolah. Mobilisasi guru sukarelawan untuk menanggulangi kekurangan guru di sekolah. Mobilisasi tenaga kependidikan nonguru untuk mengisi kekurangan di sekolah. Memantau kondisi sarana dan prasarana yang ada di sekolah. Mobilisasi bantuan sarana dan parasarana sekolah. Mengkoordinasi dukungan sarana dan parasarana sekolah. Mengevaluasi pelaksanaan dukungan sarana dan prasarana sekolah. Memantau kondisi anggaran pendidikan di sekolah. Memobilisasi dukungan terhadap anggaran pendidikan di sekolah.; Mengkoordinasikan dukungan terhadap anggaran pendidikan di sekolah. Mengevaluasi pelaksanaan dukungan anggaran di sekolah

- Pengontrol (controlling agency) dalam rangka transparansi dan akuntabilitas penyelenggaraan dan keluaran pendidikan di satuan pendidikan: Mengontrol proses pengambilan keputusan di sekolah. Mengontrol kualitas kebijakan di sekolah. Mengontrol proses perencanaan pendidikan di sekolah. Pengawasan terhadap kualitas perencanaan sekolah. Pengawasan terhadap kualitas program sekolah. Memantau organisasi sekolah. Memantau penjadwalan program sekolah. Memantau alokasi anggaran untuk pelaksanaan program sekolah. Memantau sumber daya pelaksana program sekolah. Memantau partisipasi stakeholder pendidikan dalam pelaksanaan program sekolah. Memantau hasil ujian akhir. Memantau angka partisipasi sekolah. Memantau angka mengulang sekolah. Memantau angka bertahan di sekolah.

- Mediator antara pemerintah (eksekutif) dengan masyarakat di satuan pendidikan: Menjadi penghubung antara Komite Sekolah dengan masyarakat, Komite Sekolah dengan sekolah, dan Komite Sekolah dengan Dewan Pendidikan.
Mengidentifikasi aspirasi masyarakat untuk perencanaan pendidikan. Membuat usulan kebijakan dan program pendidikan kepada sekolah. Mensosialisasikan kebijakan dan program sekolah kepada masyarakat. Memfasilitasi berbagai masukan kebijakan program terhadap sekolah. Menampung pengaduan dan keluhan terhadap kebijakan dan program sekolah. Mengkomunikasikan pengaduan dan keluhan masyarakat terhadap sekolah. Mengindentifikasi kondisi sumber daya di sekolah. Mengidentifikasi sumber-sumber daya masyarakat. Memobilisasi bantuan masyarakat untuk pendidikan di sekolah. Mengkoordinasikan bantuan masyarakat

Hubungan Sekolah dengan Komite Sekolah

Sekolah bukanlah suatu lembaga yang terpisah dari masyarakat. Sekolah merupakan lembaga yang bekerja dalam konteks sosial. Sekolah mengambil siswanya dari masyarakat setempat, sehingga keberadaannya tergantung dari dukungan sosial dan finansial masyarakat. Oleh karena itu, hubungan sekolah dan masyarakat merupakan salah satu komponen penting dalam keseluruhan kerangka penyelenggaraan pendidikan.

Adapun hubungan yang harmonis antarsekolah dan masyarakat yang diwadahi dalam organisasi komite sekolah, sudah barang tentu mampu mengoptimalkan peran serta orang tua dan masyarakat dalam memajukan program pendidikan, dalam bentuk:

- Orang tua dan masyarakat membantu menyediakan fasilitas pendidikan, memberikan bantuan dana serta pemikiran atau saran yang diperlukan sekolah.

- Orang tua memberikan informasi kepada sekolah tentang potensi yang dimiliki anaknya, dan

- Orang tua menciptakan rumah tangga yang edukatif bagi anak. 
Berkenaan dengan peningkatan hubungan sekolah dengan masyarakat, substansi pembinaannya harus diarahkan kepada peningkatan kemampuan seluruh personil sekolah dalam:

- Memupuk pengertian dan pengetahuan orang tua tentang pertumbuhan pribadi anak.

- Memupuk pengertian orang tua tentang cara mendidik anak yang baik, dengan harapan mereka mampu memberikan bimbingan yang tepat bagi anak-anaknya dalam mengikuti pelajaran.

- Memupuk pengertian orang tua dan masyarakat tentang program pendidikan yang sedang dikembangkan di sekolah.

- Memupuk pengertian orang tua dan masyarakat tentang hambatan-hambatan yang dihadapi sekolah.

- Memberikan kesempatan kepada masyarakat untuk berperan serta memajukan sekolah.

- Mengikutsertakan orang tua dan tokoh masyarakat dalam merencanakan dan mengawasi program sekolah.

Komite sekolah menurut kedudukan dan sifatnya sebagai badan mandiri yang tidak mempunyai hubungan hierarki dengan lembaga pemerintah daerah, akan tetapi dalam peran dan fungsinya komite sekolah dalam pelaksanaan MBS guna meningkatkan mutu pendidikan perlu mendapat dukungan dari seluruh komponen pendidikan, baik guru, kepala sekolah, siswa, orang tua siswa, masyarakat, dan institusi pendidikan. Oleh karena itu perlu kerja sama dan koordinasi yang erat di antara komponen pendidikan tersebut sehingga upaya peningkatan mutu pendidikan yang dilaksanakan dapat efektif dan efisien.

Peran dan fungsi tersebut telah dijabarkan secara rinci dan jelas. Namun demikian keberadaan komite sekolah masih dipandang sebelah mata oleh masyarakat. Pandangan yang lebih keras menyebut bahwa komite sekolah hanyalah tukang stempel proyek sekolah. Pandangan yang demikian tidaklah salah sepenuhnya. Fakta di lapangan menunjukkan bahwa ko- mite sekolah memang banyak yang belum menjalankan peran dan fungsinya dengan baik.

Dari pengamatan atas keberadaan komite sekolah, tidak berjalannya peran dan fungsi komite sekolah disebabkan pekerjaan komite bersifat sosial, tidak memberikan hasil secara pribadi, sementara anggota dan pengurus komite memiliki kesibukan dan profesi masing-masing. Bahkan pada beberapa kasus diketahui bahwa untuk memilih pengurus komite sekolah pun menjadi beban berat bagi sekolah. Banyak orang tua siswa maupun masyarakat tidak bersedia menjadi pengurus komite. Undang-undang dan peraturan pemerintah tentang komite sekolah juga tidak berdaya menghadapi kasus yang demikian ini.

Di satu sisi sekolah (sebagai lembaga) dalam Undang-Undang Nomor 20 Tahun 2003 tentang sistem pendidikan nasional dan Peraturan Pemerintah Nomor 17 Tahun 2010 tentang pengelolaan dan penyelenggaraan pendidikan memberikan keleluasaan untuk mengelola diri secara mandiri dengan melibatkan peran serta masyarakat. Peran inilah yang seharusnya diemban oleh komite sekolah. Namun adanya kendala di lapangan belum diperoleh solusi penyelesaian terbaik.

Persoalan lain yang dihadapi sebagian besar komite sekolah adalah belum adanya AD dan ART komite sekolah. Walaupun demikian, di beberapa sekolah komite sekolah berjalan dengan baik, meskipun belum optimal. Gambaran singkat tersebut mengindikasikan bahwa keberadaan komite sekolah belum sepenuhnya menjadi mitra andalan bagi sekolah-sekolah dasar, termasuk di Kabupaten Malang. Rendahnya partisipasi komite sekolah dasar negeri di Kabupaten Malang tersebut tampak berpengaruh pada tingkat pencapaian prestasi sekolah.

Dari keterangan yang didapatkan dari UPT Dinas Pendidikan Kecamatan Lawang Kabupaten Malang, bahwa sampai tahun 2012 belum dilakukan survei atau pengamatan tentang peran komite sekolah di wilayahnya, sehingga belum diketahui 
komite sekolah mana yang aktif maupun yang kurang aktif khususnya sekolah dasar di Kecamatan Lawang. Namun demikian pada tahun 2010 telah dibentuk paguyuban komite sekolah se-Kecamatan Lawang. Hal ini dimaksudkan untuk mewadahi dan mempermudah koordinasi maupun berbagi informasi guna meningkatkan mutu sekolah.

Mendasarkan pada informasi tersebut menarik untuk mengkaji tentang peranan komite sekolah dasar negeri di Kecamatan Lawang Kabupaten Malang, dan dalam penelitian ini dipilih Sekolah Dasar Negeri Sumberporong 03 Kecamatan Lawang Kabupaten Malang.

Sekolah Dasar Negeri Sumberporong 03 Lawang Kabupaten Malang menonjol dalam prestasi akademik maupun nonakademik. Pencapaian prestasi nilai ujian nasional se-Kabupaten Malang pada tahun 2010 berada pada peringkat 6, tahun 2011 peringkat 4 dan tahun 2012 meraih peringkat 2 . Sementara itu pencapaian prestasi nonakademik yang telah diraih, seperti juara 1 lomba atletik, juara 3 lomba english coversation tingkat Kabupaten Malang, dan masih banyak prestasi lainnya.

Dari pengamatan dan informasi awal di sekolah tersebut, peran komite sekolah cukup aktif meskipun belum optimal. Fungsi-fungsi badan pengurus terlihat berjalan baik. Hal ini sangat berbeda dibandingkan pengamatan dan pendapat umum tentang keberadaan komite sekolah yang hanya dipandang sebagai pelengkap saja. Sebagai contoh Komite SDN Sumberporong 03 Kecamatan Lawang cukup aktif turut serta dalam pembuatan RAPBS dan pengadaan sarana prasarana sekolah dengan memberikan dukungan tenaga dan pendanaan.

Namun demikian masih terlihat bahwa tidak semua pengurus dan anggota komite bisa aktif bekerja untuk kepentingan sekolah karena anggota komite yang sifatnya sukarela dan sosial mempunyai pekerjaan dan kesibukan masing-masing. Salah satu contoh adalah komite sekolah belum optimal melakukan pengawasan ter- hadap pelaksanaan proyek renovasi gedung sekolah dan hanya menerima laporan akhir dari pihak sekolah.

Selain itu para orang tua siswa masih kurang memahami perannya dalam pengembangan sekolah. Orang tua siswa menyerahkan masalah pengembangan sekolah kepada komite sekolah dan pihak sekolah, namun orang tua siswa tidak sepenuhnya mendukung keputusan sekolah apabila terlalu memberatkan bagi orang tua siswa terutama dalam hal dana.

Peran komite sekolah sebagaimana yang tertuang dalam Kepmendiknas Nomor 044 Tahun 2002 dijadikan sebagai acuan kegiatan komite sekolah. Bahkan Tim Pengembangan Komite Sekolah Ditjen Dikdasmen Depdiknas telah merinci komponen dan indikator kinerja komite sekolah terkait dengan peran yang dilakukan, yaitu sebagai badan pertimbangan, badan pendukung, badan pengontrol, dan badan penghubung.

Penelitian tentang implementasi peran komite sekolah di SD Negeri Sumberporong 03 Lawang Kabupaten Malang ini bertujuan: Untuk mengetahui dan mendeskripsikan peran komite sekolah di SD Negeri Sumberporong 03 Lawang Kabupaten Malang dalam perannya sebagai badan pertimbangan, badan pendukung, badan pengontrol, dan badan penghubung.

\section{Metode Penelitian}

\section{Jenis Penelitian}

Fokus penelitian ini adalah untuk mengungkap bagaimana peran aktif komite sekolah di SD Negeri Sumberporong 03 Lawang Kabupaten Malang. Oleh karena itu untuk mendapatkan data yang lengkap, mendalam dan memberi jawaban yang tepat terhadap masalah yang diteliti digunakan penelitian kualitatif karena SDN Sumberporong 03 menonjol dalam prestasi akademik maupun nonakademik.

\section{Waktu dan Tempat Penelitian}

Waktu penelitian dilaksanakan pada bulan Desember 2012 sampai dengan 
Maret 2013. Penelitian ini dilakukan di SD Negeri Sumberporong 03 Lawang Kabupaten Malang. Setting penelitian ini berlangsung di lingkungan tempat sekolah berada yaitu di tempat tinggal pengurus dan anggota komite sekolah sehingga diperoleh informasi tentang peran komite sekolah di SD Negeri Sumberporong 03 Lawang Kabupaten Malang.

\section{Subjek Penelitian}

Subjek penelitian adalah 1 (satu) orang ketua komite sekolah, 3 (tiga) orang anggota komite sekolah, 1 (satu) orang kepala sekolah, serta 2 (dua) orang guru yang dianggap mengetahui dan memahami peran komite SDN Sumberporong 03 Kecamatan Lawang Kabupaten Malang. Penelitian ini berusaha mencermati para informan secara teliti dengan cara berupaya menemukan informasi dari informan yang paling mengetahui topik yang diteliti. Selain itu penelitian ini juga melakukan kajian dokumentasi yang mendukung dan terkait dengan peran komite sekolah.

\section{Teknik Pengumpulan Data}

Teknik pengumpulan data yang digunakan dalam penelitian ini adalah menggunakan metode wawancara mendalam, kajian dokumen dan diskusi terhadap subjek penelitian. Teknik wawancara mendalam dalam penelitian ini ditujukan kepada pengurus dan anggota komite sekolah, kepala sekolah, serta guru sehingga diperoleh informasi yang akurat tentang peran komite sekolah di SD Negeri Sumberporong 03 Lawang Kabupaten Malang. Adapun dokumen yang diperoleh dalam penelitian ini antara lain: RKS, RAPBS, Program kerja komite sekolah, Anggaran Dasar dan Anggaran Rumah Tangga komite, surat keputusan pengangkatan komite sekolah serta foto kegiatan rapat komite bersama kepala sekolah dan orang tua siswa.

\section{Teknik Keabsahan Data}

Teknik pemeriksaan keabsahan data yang dilakukan dalam penelitian ini adalah dengan triangulasi sumber yang merupakan bagian dari kriteria derajat kepercayaan (credibility).

\section{Teknik Analisis Data}

Dalam penelitian ini, teknik analisis data yang digunakan adalah analisis model interaktif. Analisis data berlangsung secara simultan yang dilakukan bersamaan dengan proses pengumpulan data dengan alur tahapan: reduksi data (data reduction), penyajian data (data display) dan kesimpulan atau verifikasi (conclution drawing $\mathcal{E}$ verifying).

Dalam penelitian ini, reduksi data berlangsung terus-menerus selama proses penelitian berlangsung yaitu melaksanakan pemilihan data yang diperoleh dari wawancara, diskusi dengan Kepala sekolah, Komite sekolah dan Guru SDN Sumberporong 03 Lawang Kabupaten Malang dan pengumpulan dokumen-dokumen yang relevan tersebut.

\section{Hasil Penelitian dan Pembahasan}

\section{Keadaan Guru SDN Sumberporong 03}

Guru atau tenaga pengajar SDN Sumberporong 03 sebanyak 11 orang terdiri atas 5 orang guru PNS dan 6 orang guru honorer. Di samping tenaga pengajar, untuk memperlancar kegiatan pendidikan di SDN Sumberporong 03 dibantu oleh 1 (satu) orang staf tata usaha dan 1 (satu) orang tenaga kebersihan.

\section{Keadaan Siswa SDN Sumberporong 03}

Siswa SDN Sumberporong 03 untuk tahun ajaran 2012/2013 berjumlah 264 yang terdiri atas 43 siswa kelas I, 41 siswa kelas II, 48 siswa kelas III, 47 siswa kelas IV, 43 siswa kelas $\mathrm{V}$, dan 42 siswa kelas VI.

\section{Keadaan Sarana dan Prasarana}

Sekolah Dasar Negeri Sumberporong 03 memiliki sarana dan prasarana yang cukup memadai, terdiri atas gedung kelas, kantor, ruang komputer, ruang perpustakaan, ruang UKS, toilet guru dan 
siswa, mushola dan kantin. Selain itu untuk menunjang kegiatan belajar-mengajar digunakan alat peraga dan lapangan olah raga.

Sejarah Berdirinya Komite SDN Sumberporong 03

SDN Sumberporong 03 telah melaksanakan amanat pemerintah dengan respon yang baik, karena pada dasarnya, hal ini berangkat dari asumsi bahwa sekolah memilki ikatan yang sangat erat dengan masyarakat yang diwadahi dalam komite sekolah. Komite SDN Sumberporong 03 telah mengalami tiga kali pergantian pengurus. Pada awalnya komite SDN Sumberporong 03 membutuhkan waktu yang cukup lama untuk bisa menjalankan fungsi dan perannya. Hal ini terjadi karena saat itu belum semua anggota komite maupun pihak sekolah memahami apa dan bagaimana komite sekolah dan belum adanya sosialisasi maupun pembinaan dari dinas terkait.

Seiring berjalannya waktu, komite SDN Sumberporong 03 sampai dengan tahun 2013 telah menunjukkan eksistensi, fungsi dan perannya dalam mengembangkan mutu sekolah. Anggaran Dasar dan Anggaran Rumah Tangga telah disahkan pada tahun 2009, sehingga saat ini komite sekolah sudah memiliki pedoman yang jelas dalam melaksanakan tugasnya.

Struktur Organisasi Komite SDN Sumberporong 03

SDN Sumberporong 03 juga sudah disusun struktur organisasi komite SDN Sumberporong 03 yang terdiri atas ketua, wakil ketua, sekretaris, bendahara, dan seksi-seksi atau anggota. Hal ini tercantum dalam surat keputusan pengangkatan komite sekolah periode 2011-2014.

Peran Komite Sebagai Badan Pertimbangan

Komite sekolah sebagai badan pertimbangan bagi sekolah memiliki arti bahwa komite sekolah dipandang sebagai mitra kerja kepala sekolah yang dapat di- ajak bermusyawarah tentang masa depan sekolah. Melalui Komite SDN Sumberporong 03, para orang tua dan masyarakat turut serta dalam merumuskan visi, misi, tujuan, sasaran yang akan dicapai oleh sekolah, sampai dengan menetapkan cara atau strategi yang akan ditempuh untuk mencapainya yang berupa rumusan kebijakan, program, dan kegiatan sekolah.

Peran dan fungsi Komite SDN Sumberporong 03 Kecamatan Lawang Kabupaten Malang sebagai badan pertimbangan dalam melaksanakan perencanaan sekolah dimulai dari identifikasi sumber daya pendidikan dalam masyarakat, turut aktif melakukan pembahasan serta pengesahan RAPBS merupakan bagian dari peran yang dijalankan oleh Komite SDN Sumberporong 03.

Sementara itu dalam pelaksanaan program, Komite SDN Sumberporong 03 memberikan masukan terhadap proses pengelolaan pendidikan. Hal ini dibuktikan dengan memberikan masukan program tambahan jam pelajaran bagi kelas 4, kelas 5 dan kelas 6 dalam rangka menghadapi ujian nasional. Pihak sekolah menyambut baik masukan tersebut, sehingga sampai saat ini program tersebut masih berjalan dan selama ini telah menunjukkan peningkatan kualitas siswa melalui prestasi yang diraih oleh siswa SDN Sumberporong 03 Kecamatan Lawang Kabupaten Malang khususnya dalam meraih peringkat tertinggi nilai ujian nasional se-Kabupaten Malang.

Dalam pengelolaan sumber daya pendidikan baik sumber daya manusia, sarana dan prasarana maupun anggaran, Komite SDN Sumberporong 03 aktif memberi pertimbangan. Potensi sumber daya dalam masyarakat dapat diidentifikasi oleh komite secara baik, mayoritas anggota komite adalah warga asli sekitar sekolah merupakan kelebihan tersendiri bagi komite dan sekolah dalam memudahkan identifikasi sumber daya pendidikan di masyarakat. Pengelolaan terhadap tenaga kependidikan khususnya guru honorer dan karyawan tata usaha dilakukan melalui pemberian pertimbangan kepada sekolah agar men- 
dapat perhatian yang lebih dalam hal kesejahteraan sehingga dapat meningkatkan motivasi para guru dan karyawan tata usaha honorer dalam bekerja. Selain itu Komite SDN Sumberporong 03 juga berperan memberi pertimbangan dalam perekrutan guru dan karyawan tata usaha agar mendapatkan sumber daya yang berkualitas.

Dalam pengelolaan sarana dan prasarana serta anggaran sekolah, komite selalu memberi pertimbangan baik yang bersifat teknis maupun anggaran. Hal ini dibuktikan dengan adanya pembahasan bersama antara sekolah dengan komite dalam rencana dan pelaksanaan renovasi gedung sekolah tahun 2010 dan pengadaaan laboratorium komputer.

Dari beberapa uraian di atas, menunjukkan bahwa peran Komite SDN Sumberporong 03 sebagai badan pertimbangan dalam menjalankan fungsi perencanaan sekolah, pelaksanaan program dan pengelolaan sumber daya pendidikan telah berjalan dengan baik. Hal ini sesuai dengan amanat pemerintah yang tertuang dalam acuan operasioanl kegiatan dan indikator kinerja komite sekolah oleh Tim Pengembangan Komite Sekolah Ditjen Dikdasmen sebagai badan pertimbangan.

Peran Komite Sekolah sebagai Badan Pendukung

Peran komite sebagai badan pendukung dalam pengelolaan sumber daya, pengelolaan sarana dan prasarana serta pengelolaaan anggaran sebagai upaya peningkatan kualitas pendidikan dapat berupa dukungan dana, tenaga, dan dukungan pemikiran. Dukungan yang diberikan oleh Komite SDN Sumberporong 03 terhadap pemenuhan ketenagaan sekolah baik guru maupun karyawan tata usaha telah dilakukan dengan memberikan dukungan dalam perekrutan guru dan karyawan tata usaha. Bahkan saat ini komite sedang mengusulkan kepada sekolah agar segera merekrut tenaga kebersihan yang saat ini masih dirangkap oleh karyawan tata usaha.
Bentuk dukungan yang diberikan oleh Komite SDN Sumberporong 03 dalam hal sarana dan prasarana sekolah adalah selalu dilibatkan oleh sekolah dalam pembahasan rencana maupun pelaksanaannya. Pemantauan kondisi sarana dan prasarana yang dilakukan komite ditindaklanjuti dengan memberikan masukan kepada pihak sekolah. Seperti memberi masukan pengadaan laboratorium komputer yang digunakan untuk meningkatkan kualitas siswa maupun guru yang saat ini telah terealisasi dan digunakan praktik komputer bagi siswa SDN Sumberporong 03.

Selain itu, Komite SDN Sumberporong 03 juga mengkoordinir bantuan sarana dan prasarana dari masyarakat kepada sekolah. Hal ini dibuktikan dengan adanya usaha memobilisasi dan mengkoordinasi dukungan dan bantuan komputer dari donatur yang diserahkan melalui komite kepada pihak sekolah. Dukungan yang diberikan oleh Komite SDN Sumberporong 03 tidak sebatas dukungan dana, tetapi dukungan tenaga dan pikiran. Pemeliharaan komputer dan pelatihan kepada guru serta tata usaha dalam penguasaan komputer dilakukan secara sukarela oleh anggota komite yang mempunyai kapasitas dan kemampuan komputer.

Peran dan fungsi Komite SDN Sumberporong 03 sebagai badan pendukung dalam pengelolaan anggaran dilakukan dengan memantau kondisi anggaran sekolah dari laporan yang diberikan oleh kepala sekolah. Terkait dengan mobilisasi dukungan anggaran sekolah dilakukan oleh komite sekolah dengan mendorong perhatian dan bantuan dana dari masyarakat terutama warga sekitar yang sukses termasuk yang berada di luar daerah.

Dari beberapa uraian di atas, maka dapat dilihat bahwa Komite SDN Sumberporong 03 melaksanakan peran sebagai badan pendukung terkait dengan pengelolaan sumber daya, pengelolaan sarana dan prasarana serta pengelolaan anggaran. Hal ini sesuai dengan indikator kinerja komite sekolah yang diterbitkan oleh Tim Pengembangan Komite Sekolah Ditjen Dik- 
dasmen dalam perannya sebagai badan pendukung.

Peran Komite Sekolah sebagai Badan Pengontrol

Peran Komite SDN Sumberporong 03 sebagai badan pengontrol dilakukan dengan mengontrol perencanaan pendidikan di sekolah, memantau pelaksanaan program dan memantau output pendidikan. Pengawasan terhadap kebijakan dan keputusan sekolah dilakukan melalui laporan yang disampaikan oleh kepala sekolah secara tertulis atau lisan. Komite SDN Sumberporong 03 tidak melakukan kontrol secara langsung karena kesibukan anggota komite dalam profesi masingmasing. Sebagaimana yang dilakukan oleh Komite SDN Sumberporong 03 dalam mengontrol pelaksanaan renovasi gedung, proses belajar mengajar serta anggaran hanya melalui laporan yang disampaikan oleh kepala sekolah. Namun demikian, Komite SDN Sumberporong 03 melakukan pemantauan terhadap sumber daya dan alokasi anggaran. Hal ini dibuktikan dengan keikutsertaan dalam pemeriksaan laporan penggunaan anggaran sekolah dan pemantauan sumber daya pelaksana di sekolah, dalam hal ini kebutuhan dan kualitas guru serta tata usaha sekolah.

Pemeriksaan laporan keuangan sekolah dilakukan oleh Komite SDN Sumberporong 03 dengan cara memberikan copy laporan kepada anggota komite untuk diteliti dan diperiksa. Laporan penggunaan anggaran saat ini telah menggunakan format yang baku sehingga memudahkan bagi komite melakukan pemeriksaan. Sebagai bentuk kontrol dan tanggung jawab dalam penggunaan anggaran, maka Ketua Komite SDN Sumberporong 03 ikut serta dalam mengesahkan laporan tersebut.

Pemantauan terhadap output pendidikan merupakan bagian dari komite dalam menjalankan peran dan fungsinya sebagai badan pengontrol. Sebagaimana yang dilakukan oleh Komite SDN Sumberporong 03 dalam memantau hasil ujian akhir siswa, angka partisipasi sekolah, ang- ka mengulang dan angka bertahan siswa dilakukan secara berkelanjutan. Komite melakukan pemantauan melalui laporan yang disampaikan oleh kepala sekolah. Dalam hal ini adalah angka siswa mengulang, pindah maupun pindahan selalu diberikan surat oleh kepala sekolah. Pembahasan masalah tersebut dilakukan melalui rapat bersama antara sekolah, komite dan orang tua setiap semester. Perhatian lebih diberikan oleh Komite SDN Sumberporong 03 terhadap perkembangan akhlak siswa dan kesiapan guru serta siswa dalam menghadapi ujian nasional.

Dari beberapa uraian di atas, maka dapat dilihat bahwa Komite SDN Sumberporong 03 dalam menjalankan peran dan fungsinya sebagai badan pengontrol terkait dengan mengontrol perencanaan pendidikan, memantau pelaksanaan program sekolah dan memantau output pendidikan di SDN Sumberporong 03 dilakukan melalui laporan yang disampaikan oleh pihak sekolah. Kesibukan dan profesi masing-masing anggota komite menyebabkan pemantauan secara langsung belum dapat dilakukan.

\section{Peran Komite sebagai Badan Penghubung}

Peran komite sebagai badan penghubung dilakukan melalui fungsi manajemen pendidikan dalam perencanaan, pelaksanaan program dan pengelolaan sumber daya pendidikan. Dalam perencanaan, Komite SDN Sumberporong 03 menjadi penghubung antara komite dengan masyarakat, komite dengan sekolah dan komite dengan dewan pendidikan. Sebagai penghubung, Komite SDN Sumberporong 03 selalu menjalin hubungan yang baik dengan semua pihak sehingga memudahkan dalam berbagai kegiatan dan permasalahan sekolah.

Terkait dengan aspirasi masyarakat terhadap perencanaan pendidikan, Komite SDN Sumberporong 03 secara terbuka menerima segala aspirasi masyarakat demi peningkatan kualitas sekolah serta kebutuhan masyakarat. Hal ini telah dibuktikan oleh Komite SDN Sumberporong 03 yang 
saat ini sedang mengkaji dan membahas dengan pihak sekolah sehubungan dengan adanya masukan dari pemerintah desa dan masyarakat untuk menambah daya tampung siswa. Perkembangan jumlah penduduk yang pesat karena adanya perumahan baru di lingkungan sekolah membuat daya tampung bagi calon siswa sekolah dasar melebihi kapasitas sehingga saat ini banyak calon siswa yang harus menyekolahkan anaknya ke daerah lain yang jauh dan memerlukan waktu, tenaga dan biaya yang tidak sedikit.

Terkait dengan peran dan fungsi komite dalam pelaksanaan program, Komite SDN Sumberporong 03 turut serta dalam mensosialisasikan kebijakan dan program sekolah kepada masyarakat, memfasilitasi berbagai masukan, menampung pengaduan terhadap kebijakan sekolah serta mengkomunikasikan pengaduan dan keluhan masyarakat kepada sekolah. Hal ini dibuktikan dengan adanya keluhan dari orang tua siswa terkait pelajaran praktek olahraga renang yang harus membayar tiket meskipun oleh pihak pengelola pemandian diberi harga khusus yang sangat ringan. Dalam hal ini, Komite SDN Sumberporong 03 merespon pengaduan dan keluhan orang tua siswa sekaligus memberi solusi dan memfasilitasi pihak sekolah dengan menggunakan sarana milik instansi pemerintah. Dengan demikian Komite SDN Sumberporong 03 dapat memfasilitasi, menampung dan mengkomunikasikan pengaduan dan keluhan masyarakat sekaligus memberi solusi yang tepat. Hal ini tidak lepas dari terjalinnya hubungan yang baik antara komite dengan orang tua, masyarakat dan stakeholder.

Pengelolaan sumber daya pendidikan di SDN Sumberporong 03 dalam mengidentifikasi kondisi sumber daya khususnya di masyarakat sekaligus mobilisasi dan koordinasi bantuan masyakarat juga dilakukan oleh komite sekolah. Mayoritas Pengurus Komite SDN Sumberporong 03 adalah warga di lingkungan sekolah merupakan kelebihan tersendiri bagi pihak Komite dan sekolah. Komite lebih memahami kondisi sumber daya masyara- katnya dan memudahkan melakukan mobilisasi dan mengkoordinasikan bantuan masyarakat. Hak ini dibuktikan dengan adanya bantuan berbagai pihak kepada sekolah saat kegiatan Persami SD se-Kecamatan Lawang yang dilaksanakan di lingkungan SDN Sumberporong 03. Komite memobilisasi dan mengkoordinasikan kebutuhan dan bantuan masyarakat, seperti kebutuhan lampu penerangan dan keamanan kegiatan.

Dari beberapa uraian di atas, maka dapat dilihat bahwa Komite SDN Sumberporong dalam peran dan fungsinya sebagai badan penghubung telah berjalan sesuai dengan indikator kinerja komite sekolah sebagaimana yang telah diuraikan dalam kajian teori yaitu acuan indikator kinerja komite sekolah yang diterbitkan oleh Tim Pengembangan Komite Sekolah Ditjen Dikdasmen Depdiknas.

\section{Simpulan dan Saran}

Simpulan

Komite SDN Sumberporong 03 berperan aktif dalam memberikan pertimbangan dan masukan pelaksanaan kebijakan pendidikan serta pengelolaan sumber daya pendidikan di SDN Sumberporong 03 sesuai dengan acuan operasional kegiatan dan indikator kinerja komite.

Komite SDN Sumberporong 03 berperan aktif dalam memberikan dukungan terhadap pengelolaan sumber daya, pengelolaan sarana dan prasarana, dan pengelolaaan anggaran pendidikan di SDN Sumberporong 03.

Komite SDN Sumberporong 03 dalam mengontrol kebijakan dan pelaksanaan program sekolah secara langsung belum optimal. Pemantauan hanya dilakukan secara pasif yaitu melalui laporan yang diberikan pihak sekolah serta apabila ada pengaduan maupun keluhan dari orang tua siswa dan masyarakat.

Komite SDN Sumberporong 03 telah menjalankan perannya sebagai badan penghubung dalam fungsi perencanaan, pelaksanaan program serta pengelolaan 
sumber daya pendidikan di SDN Sumberporong 03 Kecamatan Lawang Kabupaten Malang.

\section{Saran}

Karena keterbatasan sumber dana yang ada sebagai kendala dalam melaksanakan program yang terkait dengan program komite sekolah dan sekolah, maka diharapkan pihak sekolah dan Komite SDN Sumberporong 03 dapat mencari terobosan baru yang dapat menggali dan menghasilkan dana untuk menunjang keberhasilan program peningkatan mutu pendidikan melalui kerja sama dengan stakeholder.

Peran dan fungsi komite sekolah yang sangat kompleks memerlukan tenaga, pikiran dan waktu serta biaya yang tidak sedikit, untuk itu dibutuhkan keseriusan dan konsistensi dalam pelaksanaannya sehingga bukan menjadi kegiatan sampingan dan bersifat sosial. Untuk itu diharapkan adanya perhatian semua pihak khususnya pemerintah daerah agar lebih mem-perhatikan komite sekolah sebagai lembaga yang dapat mengimplementasikan peran dan fungsinya sesuai dengan amanat UndangUndang Nomor 20 Tahun 2003 tentang Sistem Pendidikan Nasional, dengan memberikan insentif yang diatur dengan peraturan yang memiliki kekuatan hukum.

\section{Daftar Pustaka}

Depdikbud. (2003). Acuan operasional kegiatan dan indikator kinerja komite sekolah. Jakarta: Depdiknas.

. (2002). Keputusan Menteri Pendidikan Nasional RI Nomor 044, Tahun
2002, tentang Dewan Pendidikan dan Komite Sekolah.

. (2004). Panduan umum dewan pendidikan dan komite sekolah. Jakarta: Depdiknas.

Nanang Fattah. (2004). Konsep manajemen berbasis sekolah dan dewan sekolah. Bandung: Pustaka Bani Quraisy.

Tim Pengembangan Komite Sekolah Ditjen Dikdasmen Depdiknas. Indikator kinerja komite sekolah. Diambil pada tanggal 29 Juli 2012, dari http : L/dikdas.kemendiknas.go.id/docs $\angle$ doc_9.pdf.

(2003). Acuan operasional kegiatan dan indikator kinerja komite sekolah. Diambil pada tanggal 29 Juli 2012, dari http ://dikdas.kemendiknas. go.id/docs/doc_9.pdf.

(2003). Acuan operasional kegiatan dan indikator kinerja komite sekolah. Diambil pada tanggal 29 Juli 2012, dari http ://dikdas.kemendiknas. go.id/docs/doc_9.pdf.

Peraturan Pemerintah R.I. Nomor 25, Tahun 2000, tentang Kewenangan Pemerintah dan Kewenangan Propinsi sebagai Daerah Otonom.

Peraturan Pemerintah Nomor 17, Tahun 2010, tentang Pengelolaan dan Penyelenggaraan Pendidikan.

Undang-Undang RI Nomor 25, Tahun 2000, tentang Program Pembangunan Nasional (Propenas) Tahun 2000-2004. Undang-Undang RI Nomor 20, Tahun 2003, tentang Sistem Pendidikan Nasional. 